Paper

\title{
The honours learning environment of Windesheim University of Applied Sciences
}

Tineke Kingma ${ }^{1 *}$, Karien Dommerholt ${ }^{2}$, Liesbeth Rijsdijk ${ }^{3}$

1. Managing director Honours Programmes, senior education consultant and researcher, Windesheim University of Applied Sciences, The Netherlands, t.kingma@windesheim.nl

2. Consultant, deBreedte, The Netherlands, karien@debreedte.nl

3. Managing director external \& international affairs Windesheim Honours College and senior teacher and researcher, Windesheim University of Applied Sciences, The Netherlands, E.Rijsdijk@windesheim.nl

*_Corresponding author: t.kingma@windesheim.nl

Received: 10 September 2017; Accepted: 29 September 2017; Published: 30 October 2017

\begin{abstract}
This paper presents the application of theories and experiences in the day-to-day environment of honours education in a so-called honours learning environment. In 2009, Windesheim University of Applied Sciences (UAS) started with honours education. An important question from the start was: what characterizes the honours learning environment? Based on experience, knowledge exchange and input from theory, the honours learning environment was developed, which is the fundament of honours and talent development at Windesheim UAS. The eight characteristics are illustrated by animations and explanations based on scientific studies.
\end{abstract}

Keywords: honours learning environment, higher education, honours pedagogy, honours programmes, co-creation

\section{Introduction}

Honours education at Windesheim University of Applied Sciences is specially designed education for ambitious, motivated students who want to do more than the regular programme offers (Wolfensberger, 2015). These programmes aim at providing highachieving and motivated students enriched learning experiences (Byrne, 1998), focused on broadening and creating new knowledge with special attention for more generic competences (Allen et al., 2015). They meet the needs of talented students to experiment and go beyond the beaten tracks (Wolfensberger, Pilot, \& Van Eijl, 2012) and offer possibilities to students to distinguish themselves (Allen et al., 2015). Talents from our point of view are strengths which make individuals stand out, compared to others. The Gallup's research (Rath, 2007) has shown that a strengths-based approach improves the confidence, 
direction, hope, and kindness towards others and individuals are six times more likely to be engaged in their job. A strengths-based approach leads to stronger teams. In honours education, teachers, motivated and gifted students and professionals work together. They all play an important role in this cooperation. Windesheim has made a choice to not name every target group separately but instead to describe the environment in which these actors work together: the Windesheim honours learning environment. Based on almost ten years of development of an honours learning environment and implementation of honours education at Windesheim, we developed a framework of an honours learning environment. This framework includes results from studies (Janssen, 2017; Renzulli, 2005; Scager, Akkerman, Pilot, \& Wubbels, 2013; Simons, 1999; Sternberg, 2003), from experiences and from learning theories such as positive psychology (Seligman, Ernst, Gillham, Reivich, \& Linkins, 2009), Appreciate Inquiry (Cooperrider, Whitney, \& Stavros, 2008), differentiation in pedagogy (Janssen, 2017; Kok, 2003), experiential learning (Kolb \& Kolb, 2005), selfdetermination theory (Ryan \& Deci, 2017) and honours pedagogy (Scager, Akkerman, Pilot, \& Wubbels, 2014; Wolfensberger, 2012). Apart from this framework, we made use of already formulated characteristics of honours students; what makes a student "honours"?

\section{Characteristics of honours students}

Honours students do not form a homogeneous group, but different studies (Achterberg, 2005; Kazemier, Offringa, Eggens, \& Wolfensberger, 2014; Kingma, Kamans, HeijnePenninga, \& Wolfensberger, 2016; Wolfensberger \& Offringa, 2012) show the following characteristics as being often present in honours students:

- $\quad$ They are eager, wanting to investigate and experience things and they want to experiment

- $\quad$ They are intrinsically motivated, ambitious and score high on autonomy

- $\quad$ They appreciate the freedom to work on their development

- More often than average they participate in volunteer work or activities outside of their studies because they find them fun or meaningful

- $\quad$ They generally have a broad interest and are strongly service-oriented

- Honours students are generally enthusiastic, result-oriented and self-directing, but can at the same time also be shy, anxious or risk-averse

- Honours students can be impatient when it comes to bureaucracy

- $\quad$ They are mostly open to new experiences and are conscientious.

Honours students value the following points in honours programmes, in order of importance (Van Eijl, Pilot, \& Wolfensberger, 2010):

- $\quad$ Student-teacher interaction

- Community formation

- $\quad$ Practice-orientedness and authenticity

- Room for initiative

- Small scale of the organization

- Mutual choice for participation

- An interest in other areas than their study programme

- Quality of the teacher as a condition.

Motivated students have a strong need for a teacher who supports them in their need for autonomy (Núñez, Fernández, León, \& Grijalvo, 2014). In order to be able to make honours 
programmes successful for students, it is important to keep feeding their intrinsic motivation. Research done by Wolfensberger (2012) shows three pillars of honours pedagogy that are characteristic for teaching in honours programmes. These pillars are: creating community, stimulating academic competencies and offering freedom. They show a strong resemblance to the self-determination theory. The self-determination theory (Ryan \& Deci, 2000; 2017) tells us that intrinsic motivation of students in general is fed when three psychological basic needs are met, which are autonomy, competence (mastery) and connectedness. This asks for an autonomy-supportive learning environment in which a teacher, apart from connectedness, can also offer a good balance between autonomy and structure (Pintrich \& De Groot, 1990; Reeve, 2009; Sierens, Vansteenkiste, Goossens, Soenens, \& Dochy, 2009). Teachers can meet these by means of their teaching style. Supporting freedom in learning is a vital linchpin for developing intrinsic motivation for learning (Kusurkar, 2012).

\section{Windesheim honours learning environment}

The Windesheim Honours learning environment consists of eight characteristics which support learning by honours students through: (1) multidisciplinary connections; (2) creative productivity; (3) authentic assignments; (4) personal learning journey; (5) social responsibility; (6) concept of giftedness; (7) learning communities and (8) personal leadership. These eight characteristics are input for the content and design of the honours programme and are based on both scientific research and application of this knowledge in the day-to-day environment of honours education within Windesheim UAS since 2007, when we started developing honours education. All honours education at Windesheim UAS meets the eight characteristics of the honours learning environment, whereas the content can differ from one programme to the next.

Within the Honours learning environment a crucial role is allocated to its participants who interact and collaborate with each other in the environment. The characteristics are not about the physical learning environment, but about the behaviour and attitudes needed from the teachers, students and other people from outside the university and ways of cocreation between different actors.

In figure 1 all characteristics are summarized in the model of the Honours learning environment. 


\section{Honours learning environment}

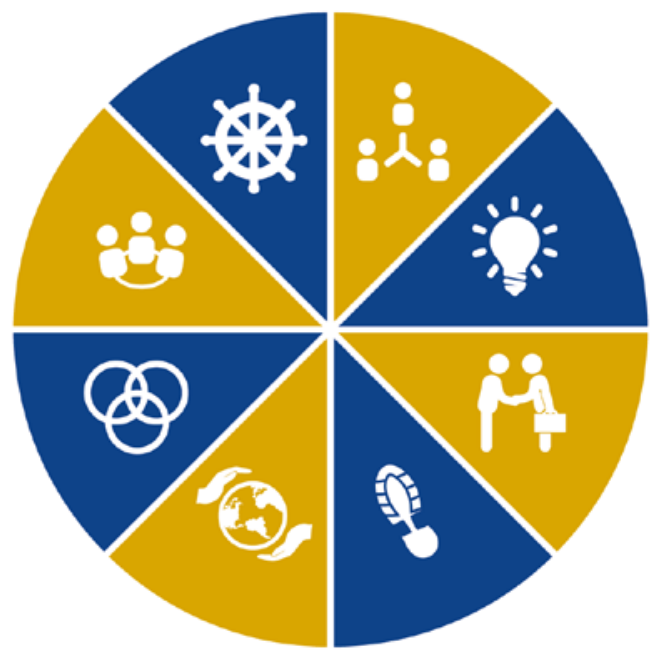

Multidisciplinary Connections

Creative Productivity

Authentic Assignments

Personal Learning Journey

Social Responsibility

Concept of Giftedness

Learning Communities

Personal Leadership

Windesheim

Source: Kingma, Meijer, Veltman, \& Zwier, 2016

Below a brief description per characteristic is given. For all actors (students, teachers and external professionals) a suggestion of desired behaviour, attitude or skill to fulfil the characteristic is worked out. Furthermore, all characteristics are explained by an animation which can be reached by clicking the link. All animations are directed to teachers.

\section{Characteristic 1: Multidisciplinary Connections}

\section{Multidisciplinary Connections}

In an honours learning environment there is a broadening of cooperation in comparison with the student's own study programme, either in a multidisciplinary or an international context (Jansen \& Suhre, 2015; Janssen, 2017; Veerman, Kingma, Van Alphen, Smits, \& Jukema, 2017). Multidisciplinary connections are important to solve complex problems. The synergy between different backgrounds who bring in views from different disciplines combined with personal qualities and talents is key to come up with solutions for these problems. People in different professional roles get the opportunity to rub against sectors and execute different tasks. Broadening one's own work field, while preserving one's own professional identity and contributing to education or professional training. Internationalization can be part of the multidisciplinary connections but is not absolutely necessary.

Teacher

- $\quad$ Creating space and time in order to be able to give a lot of attention to critical and independent thinking, and role-modelling this

- $\quad$ Searching for various ways and forms to bring in different points of view 
- $\quad$ Challenging students to put in, to fill up and to empty their baggage of knowledge and experience again, when working with other approaches and methods of working

- $\quad$ Asking students about the underpinning of their viewpoints on why things are or aren't working

- $\quad$ Building in room to get to know each other's backgrounds

- $\quad$ Facilitating connection to each other.

Student

- $\quad$ Curiosity about different approaches

- $\quad$ Gaining consciousness of similarities and differences in types of approach by different study programmes

- $\quad$ Openness to and wonder about 'never having thought of that'.

External professional

- $\quad$ Bringing in strategic problems that demand an approach from multiple perspectives.

\section{Characteristic 2: Creative Productivity}

\section{Creative Productivity}

In an honours learning environment, it is not only about generating new ideas, but also about analysing the usability of these ideas and delivering advice for implementation (Sternberg, 2003). The skills actors use to be more creative are learning by designing, using a design cycle, design thinking and making prototypes. All skills are used iteratively to assure progressing step by step. Another factor can be an analysis up front and broadening the research. Assignments are open-ended and students may come up with something the teacher doesn't know about yet.

\section{Teacher}

- $\quad$ Challenging students to take an extra step in research, implementation and measuring effectiveness of implementation

- Within the assignments building in the option for students to come up with their own ideas on content and approach

- Within the assignments building in activities during which students investigate issues and underpin their findings with facts, arguments and reasoning

- Within the assignments using activities that lead to creating, comparing and balancing.

Student

- $\quad$ Not satisfied with the first result

- Critical reflection

- $\quad$ Creative thinking

- $\quad$ Coming up with one's own ideas is allowed. 
External professional

- $\quad$ Being open to the unknown, offering room to experiment.

\section{Characteristic 3: Authentic Assignments}

\section{Authentic Assignments}

Intrinsically motivated students like working on assignments for a real organization. Authentic assignments are an important source of nourishment to keep feeding intrinsic motivation (Allen et al., 2015; Cremers, Wals, Wesselink, \& Mulder, 2016). Meaningful and real assignments where the results can really be used in practice because there is an urgency, motivates the assignment giver and taker. The assignments should be innovative and open-ended with room for ownership by the student.

\section{Teacher}

- $\quad$ Entering into cooperation with real organizations and especially from other professional fields than just the student's own field of training

- $\quad$ Using assignments in such a way, that students can work on them for a longer period of time in order to achieve more depth and establish a situation of being allowed to learn from trial and error

- $\quad$ Taking the experience from the way of working with the assigning organizations in one's design and translating it into a hybrid environment

- Using manners of cooperation in which a broadening of perspective is searched for

- $\quad$ Finding a balance in the method of guidance between the autonomy of the student while working on the assignment and supporting this autonomy by facilitating real learning

- $\quad$ Together with the assigning organization fine-tuning the freedom and room for the students to learn and - for the benefit of organization - the quality of the final result

- $\quad$ Facilitating a win-win situation together with the assigning organization and the student.

Student

- $\quad$ Students have the responsibility for rounding off the assignment, for the sake of which the organization must be heard, the problem must be closely defined and both parties must have committed themselves to the final product.

External professional

- Willingness to manage expectations for the learning process of the student, the quality requirements of the final product and the cooperation with Windesheim staff

- Offering room to students to be allowed to learn, experiment and sometimes also to fail. 


\section{Characteristic 4: Personal Learning Journey}

\section{Personal learning journey}

In an honours learning environment students are given the room to discover, to develop and to put in their own strengths and discover true and full individual potential. The studentteacher relationship and personal coaching, as well as working on their personal development in small groups of fellow students, contribute to this. The relationships are characterized by a high amount of trust and openness (the whole person). Guidance within the honours learning environment requires a lot of attention to the talents and need for extra challenge of the students. Via a presentation about their personal learning journey, the student can profile himself professionally and personally (Rath, 2007; Van Eijl \& Pilot, 2016). It starts with commitment to actively get to work with one's qualities and possibilities of growth. The result is to become conscious of one's own qualities and possibilities of growth and self-knowledge and even express them. Fascination, passion and sparkling of the eyes caused by finding one's intrinsic motivation is a beautiful result of this.

Teacher

- Is genuinely interested in getting to know the student and what drives him

- $\quad$ Gets satisfaction from seeing the personal learning journey of the student

- Is open and accessible to the student.

Student

- $\quad$ Being open to discovering who one is

- $\quad$ Being open to and having the courage to experiment

- Investigating and understanding what is meaningful to you

- $\quad$ Committing to personal growth.

External professional

- $\quad$ Acts as a critical friend who gives feedback based on questions by the student and on the consistency in the student's story with the purpose to get ahead step by step in the question of 'how can I improve'

\section{Characteristic 5: Social Responsibility}

Social responsibility

With its varieties of honours programmes, Windesheim aims to encourage students "to question the status quo" in order to contribute to the world of tomorrow and to share in the responsibility for the common good. That means that honours education is focused on creating value for/in society, leadership, entrepreneurship and innovation. Daring to ask fundamental questions about general assumptions in society and systems/structures, such as those concerning sustainability and social justice is part of this. What systemic changes in social structures - economic, social, political - are necessary for a sustainable, inclusive society? And what changes are required at an individual level in our thoughts and actions, in doing and being? Responsibility in society is especially important when forming a strong 
sense of purpose: the student defines his own purpose that exceeds his own individual wellbeing (Clevenger-Bright et al., 2012). Students can create value in the broad sense of the word (people - planet - profit).

Teacher

- $\quad$ How can you tell that our students are societally responsible?

- $\quad$ Ask students about how they want to make the difference.

Student

- $\quad$ Being open to and curious about societal problems and wanting to contribute to solving them

- $\quad$ Treating each other with respect.

External professional

- In consultation, working on societal themes that matter

\section{Characteristic 6: Concept of Giftedness}

\section{Concept of giftedness}

Renzulli (2005) expresses creative-productive talent in the Three-Ring Conception of giftedness by means of the combination of the following three personality traits: a score above average on professional abilities, perseverance and creativity. The honours environment feeds all three (Renzulli, 2005). Wanting to make the difference more than the group you belong to metacognitively, analytically or in one of the other forms of intelligence (Gardner, 2004) are examples of scoring above average. It is especially the combination of the three personality traits of Renzulli where giftedness is seen.

Teacher

- $\quad$ Tuning assignments to the common ground between the three personality traits

- Optimally designing the honours learning environment to keep developing the student's full potential.

Student

- $\quad$ Distinguishing oneself from peers

- Discovering one's full potential

- $\quad$ Showing one's motivation to make the difference.

External professional

- $\quad$ Challenging students to move a step forward. 


\section{Characteristic 7: Learning Communities}

\section{Learning Communities}

In an honours learning environment students work together with fellow students, teachers and external parties in a learning community. The community offers the safety to experiment and stimulates room for the autonomy and personal growth of the student (Coppoolse, Van Eijl, \& Albert, 2013; Wolfensberger, 2012). One key element is that the actors within the community are highly motivated and open minded. The learning community needs to be a safe environment where actors have faith in each other. Learning and developing is not only dedicated to students. Teachers and assignment givers learn as well.

Teacher

- $\quad$ Creating situations in which mutual learning and making mistakes are possible

- No traditional teacher-student relationship, but one based on equality

- Using classroom activities, methods of guidance and questions that feed and stimulate curiosity.

Student

- Wanting to share and connect things together with peers

- $\quad$ Being curious for the other's perspective

- No traditional teacher-student relationship, but one based on equality.

External professional

- Openness to learning together.

\section{Characteristic 8: Personal Leadership}

Personal leadership

Ambitious students show a pro-active attitude and take charge of their own development within the honours learning environment, as well as outside it, while continually building on their personal learning journey (Clark, Osterwalder, Pigneur, \& Van der Pijl, 2012; Rath, 2007). Being one's own director and being in the driver's seat inside the secure honours learning environment makes students see, create and use opportunities inside and outside the honours learning environment.

\section{Teacher}

- $\quad$ Asking different types of questions, not settling for the first answer, coaching

- Showing a genuine interest in what drives and challenges the student to take extra steps.

Student

- $\quad$ Setting, implementing and executing one's own objectives, learning outside of one's comfort zone, developing personal development skills

- $\quad$ Daring to keep challenging oneself 
- $\quad$ Daring to look at oneself critically

- $\quad$ Creating one's own network to continue to feed one's personality

- $\quad$ Spotting people who can help you along in your personal development

- $\quad$ Daring to ask, daring to experiment and daring to fail.

External professional

- $\quad$ Being an inspiration

- $\quad$ Being prepared to enter into relationships based on equality.

\section{Concluding remarks}

In 2016, the honours learning environment was implemented within Windesheim UAS. It is used to develop new honours programmes and to review current honours programmes. In 2018 we will arrange a peer review by and with all honours programmes in order to evaluate how these characteristics support the learning of honours students and how it can be improved.

There are three concluding remarks we would like to share:

1. The honours learning environment is designed as a model for teachers to think critical about their behaviour and attitude in education in order to challenge motivated and gifted students who want to do more than the regular programme offers. The result is a model that invites teachers to a discussion about the different aspects of an honours environment. But besides the teachers, it can also be used by other actors as well. Students are invited to think about the honours programmes and their own role. An improvement can be to add good practices and more research aimed at students or external professionals. Especially the characteristic 'Concept of giftedness' could then improve.

2. The model describes the characteristics of an honours learning environment where three different actors meet. There is no pinpointing to one specific actor. This makes the model impersonal and the description invites all actors to think critically about their role in order to make the learning experience within the honours learning environment a success.

3. The eight characteristics of the honours learning environment are not fixed and we expect that they might provide enough freedom to experiment because the focus is not on the content of a programme, but on the characteristics of an honours learning environment. Learning experiences in this environment might have a radiation effect on regular education when talking about what the application of a characteristics might mean for the context of regular programmes.

\section{References}

Achterberg, C. (2005). What is an Honors Student? Journal of the National Collegiate Honors Council, 6(1), 75-83.

Allen, J., Belfi, B., Van der Velden, R., Jongbloed, B., Kolster M. Phil., R., Westerheijden, D., ... Wolbers, M. (2015). 'Het beste uit studenten': onderzoek naar de werking van het Sirius 
Programma om excellentie in het hoger onderwijs te bevorderen. Available online: http://doc.utwente.nl/98812/ (accessed 26/2/2016)

Byrne, J. P. (1998). Honors Programs in Community Colleges: A Review of Recentlssues and Literature. Community College Review, 26(2), 67-81.

Clark, T., Osterwalder, A., Pigneur, Y., \& Van der Pijl, P. (2012). Business model you - Een methode om je carrière opnieuw uit te vinden: op één A4'tje: Vakmedianet.

Clevenger-Bright, M., Hays, K., Henricksen, L., Hlebain, D., Maglalang, J., Packard, M., ... Raftus, D. (2012). What is service learning? Paper presented at the Learning Community, Washington.

Cooperrider, D. L., Whitney, D. K., \& Stavros, J. M. (2008). The Appreciative Inquiry Handbook: For Leaders of Change (Vol. 2nd ed). Brunswick, OH: Berrett-Koehler Publishers.

Coppoolse, R., Van Eijl, P. J., \& Albert, P. (2013). Hoogvliegers: ontwikkeling naar professionele excellentie. Rotterdam: Rotterdam University Press Hogeschool Rotterdam.

Cremers, P. H. M., Wals, A. E. J., Wesselink, R., \& Mulder, M. (2016). Design Principles for Hybrid Learning Configurations at the Interface between School and Workplace. Learning Environments Research, 19(3), 309-334.

Gardner, H. (2004). Frames of mind: The theory of multiple intelligences. New York, NY, US: Basic Books.

Jansen, E. P. W. A., \& Suhre, C. J. M. (2015). Factors influencing students' perceptions of graduate attribute acquisition in a multidisciplinary honours track in a Dutch university. Higher Education Research \& Development, 34(6), 1138-1152.

doi:10.1080/07294360.2015.1024626

Janssen, F. (2017). Grip krijgen op complexiteit. Onderwijs voor het 'moeras'. [Oratie]. Available online: https://openaccess-leidenuniv-nl.proxyub.rug.nl/bitstream/handle/1887/51601/OratieJanssen.pdf?sequence=1 (accessed 3-92017)

Kazemier, K. M., Offringa, G. J., Eggens, L., \& Wolfensberger, M. V. C. (2014). Motivatie, leerstrategieën en voorkeur voor doceerbenadering van honoursstudenten in het hbo. Tijdschrift voor Hoger Onderwijs, 4(1), 106-124.

Kingma, T., Kamans, E., Heijne-Penninga, M., \& Wolfensberger, M. V. C. (2016). De autonomie-ondersteunende doceerstijl in excellentieprogramma's: de invloed van mindset, motivatie en druk vanuit de sociale werkomgeving. Tijdschrift voor Hoger Onderwijs, 34(1), 5-22.

Kingma, T., Meijer, M., Veltman, M., \& Zwier, H. P. (2016). Educational Reference Framework Hogeschoolbrede Windesheim Honours programma's. Zwolle: Interne notitie Windesheim. 
Kok, J. J. M. (2003). Talenten Transformeren. Over het nieuwe leren en leerarrangementen. Oratie 19 juni 2003. Eindhoven: Fontys Hogescholen.

Kolb, A. Y., \& Kolb, D. A. (2005). Learning Styles and Learning Spaces: Enhancing Experiential Learning in Higher Education. Academy of Management Learning \& Education, 4(2), 193-212. doi:10.5465/AMLE.2005.17268566

Kusurkar, R. A. (2012). Motivation in medical students. Oisterwijk, Utrecht. Available online: http://dspace.library.uu.nl/handle/1874/234627 (accessed 7-1-2015)

Núñez, J. L., Fernández, C., León, J., \& Grijalvo, F. (2014). The relationship between teacher's autonomy support and students' autonomy and vitality. Teachers and Teaching, 21(2), 191202. doi:10.1080/13540602.2014.928127

Pintrich, P. R., \& De Groot, E. V. (1990). Motivational and self-regulated learning components of classroom academic performance. Journal of educational psychology, 82(1), 33-40. doi:0022-0663/90/\$00.75

Rath, T. (2007). StrengthsFinder 2.0. New York: Gallupp Press.

Reeve, J. (2009). Why teachers adopt a controlling motivating style toward students and how they can become more autonomy supportive. Educational Psychologist, 44(3), 159-175. doi:10.1080/00461520903028990

Renzulli, J. S. (2005). The three-ring conception of giftedness: A developmental Model fer Promoting Creative Productivity. In R. J. Sternberg \& J. E. Davidson (Eds.), Conceptions of Giftedness (pp. 246-279). New York: Cambridge University Press.

Ryan, R. M., \& Deci, E. L. (2000). Self-determination theory and the facilitation of intrinsic motivation, social development, and well-being. The American Psychologist, 55(1), 68-78. doi:10.1037110003-066X.55.1.68

Ryan, R. M., \& Deci, E. L. (2017). Self-determination theory: Basic psychological needs in motivation, development, and wellness. New York, NY, US: Guilford Press.

Scager, K., Akkerman, S. F., Pilot, A., \& Wubbels, T. (2013). How to persuade honors students to go the extra mile: creating a challenging learning environment. High Ability Studies, 24(2), 115-134. doi:10.1080/13598139.2013.841092

Scager, K., Akkerman, S. F., Pilot, A., \& Wubbels, T. (2014). Challenging High-Ability Students. Studies in Higher Education, 39(4), 659-679.

Seligman, M. E. P., Ernst, R. M., Gillham, J., Reivich, K., \& Linkins, M. (2009). Positive education: positive psychology and classroom interventions. Oxford Review of Education, 35(3), 293-311. doi:10.1080/03054980902934563 
Sierens, E., Vansteenkiste, M., Goossens, L., Soenens, B., \& Dochy, F. J. R. C. (2009). The synergistic relationship of perceived autonomy support and structure in the prediction of self-regulated learning. British Journal of Educational Psychology, 79(1), 57-68.

doi:10.1348/000709908X304398

Simons, P. R. J. (1999). Three Ways to Learn in a New Balance. Lifelong Learning in Europe, 4(1), 14-23.

Sternberg, R. J. (2003). WICS as a model of giftedness. High Ability Studies, 14(2), 109-137. doi:10.1080/1359813032000163807

Van Eijl, P. J., \& Pilot, A. (Eds.). (2016). The Honours Experience. Talentontwikkeling door de ogen van de honoursstudent. Rotterdam: Hogeschool Rotterdam Uitgeverij.

Van Eijl, P. J., Pilot, A., \& Wolfensberger, M. V. C. (Eds.). (2010). Talent voor morgen. Groningen: Noordhoff.

Veerman, M., Kingma, T., Van Alphen, J., Smits, C. H. M., \& Jukema, J. S. (2017). Living Lab: intrinsiek motiveren door co-creëren. OnderwijsInnovatie, 19(1), 32-35.

Wolfensberger, M. V. C. (2012). Teaching for Excellence. Honors Pedagogies Revealed. Waxmann, Münster.

Wolfensberger, M. V. C. (2015). Talent Development in European Higher Education. Honors Programs in the Benelux, Nordic and German-Speaking Countries. London: Springer Open. doi: 10.1007/978-3-319-12919-8

Wolfensberger, M. V. C., \& Offringa, G. J. (2012). Qualities Honours Students Look for in Faculty and Courses, Revisited. Journal of the National Collegiale Honors Council, 13(2), 171183.

Wolfensberger, M. V. C., Pilot, A., \& Van Eijl, P. J. (2012). Laboratories for Educational Innovation: Honors Programs in the Netherlands. Journal of the National Collegiate Honors Council, 13(2), 149-170. 